\title{
Mary-Anne Elizabeth Plaatjies-Van Huffel: Curriculum Vitae
}

\section{Personal Information}

Mary-Anne Elizabeth Plaatjies-Van Huffel was born on 15 December 1959 in Prieska, as the second eldest of seven daughters born to Johannes and Jacoba Plaatjies. She matriculated at the Bergrivier Senior Secondary School in Wellington in 1977, completed her teacher's diploma at the Universiy of Western Cape in 1978, and started her teacher's career. In 1986 she enrolled at the University of the Western Cape to pursue her studies to become a minister in the Dutch Reformed Mission Church. Mary-Anne was married to Rev. Dawid Van Huffel, a minister of the Uniting Reformed Church in Southern Africa (URCSA) congregation Scottsdene in Kraaifontein near Cape Town. She served as a minister of the Robertson East congregation until March 2010. She obtained two doctoral degrees: one from the University of South Africa in 2003, and another from the University of Pretoria in 2008. In 2010 she was appointed as lecturer in Church History and Church Law (Ecclesiology) in the Faculty of Theology at the University of Stellenbosch (US). At US she was promoted to associate professor in 2015 and to full professor in Ecclesiology in 2019. In the almost 60-year history of the Faculty of Theology she was the first Black woman to be appointed as a full professor. She also served as Head of the Unit for Religion and Law in the Beyers Naudé Centre for Public Theology. Her academic contributions extended further to URCSA and the Dutch Reformed Church (DRC) Theological Seminary in the Faculty of Theology, where a new model for spiritual formation was developed in 2012. It was here that her design of the programme of practical training for theological formation was applied and fully operational from 2012, after being approved by the General Synod of the URCSA. Apart from her academic career, she was highly regarded as ecumenical church leader. Not only was she ordained as the first woman in the Dutch Reformed family of churches in South Africa in November 1992, but she was also the first woman to be appointed Moderator of the General Synod of the Uniting Reformed Church in Southern Africa. Until her death in 2020 she also served as the President of the World Council of Churches, representing Africa from 2013.

\section{UNISA}




\section{Formal Education}

- 1991 BTh (Hons), University of the Western Cape

- 1998 MTh: "Is die Kerk Middeleeus? 'n Kritiese studie oor die geloofs- en kerklike praksis met betrekking tot prostitusie in die NGK familie in die KaapseSkiereiland." University of the Western Cape

- 2003 DTh: "Vroue in die teologiese antropologie in die Afrikaanse Gereformeerde tradisie." University of South Africa

- 2008 PhD: "Die Doleansie Kerkreg en Kerkregering van die Nederduitse Gereformeerde sendingkerke en die VGKSA." University of Pretoria

\section{Professional Positions}

- 2010 Associate Professor in Ecclesiology and Church Polity, Stellenbosch University

- 2010 Minister of the Word in URCSA Robertson East congregation until 28 March

- 2010 Since 1 April 2010 co-pastor in the URCSA Scottsdene

- 2007 Temporary Lecture in Systematic Theology, Hugenote College

\section{Awards}

- Recipient of the Rector's award: In 2013 she received the Rector's award at Stellenbosch University for research outputs during 2011

- Recipient of Provincial Honours: In 2004 she received the Premier's Commendation Certificate from Marthinus Christoffel Johannes van Schalkwyk, Premier of the Province of Western Cape, in terms of section 2 of the Western Cape Provincial Honours Act, 1999 (Act 9 of 1999), for work amongst impoverished people in the Robertson area

\section{Academic and Professional Activities}

- Read 23 academic and 17 non-academic papers at national and international conferences

- Acted as keynote speaker at several national and international conferences

- Reviewer of:

- Articles in accredited journals, inter alia the Nederduits Gereformeerde Teologiese Tydskrif, Stellenbosch Teologiese Tydskrif, Studia Historiae Ecclesiasticae, Scriptura, Acta Theologica, Hervormde Teologiese Studies, Verbum et Ecclesia; and

- Books for the Andrew Murray/Desmond Tutu book award 2011

- From 2010-2017 she supervised 26 post-graduate students (PhD 4; MTh 6; MDiv 8; BDiv 3; PGD 5) 
- External examiner for the University Western Cape-B.Th. Hons Systematic Theology and PhD Systematic Theology/Ecclesiology; Heidelberg College-B.Th. IV Ecclesiology, North-West University—PhD; and University Pretoria-MTh and $\mathrm{PhD}$

\section{Membership of Associations}

- Suid-Afrikaanse Akademie vir Wetenskap en Kuns (2013-2020)

- International Consortium for Law and Religion Studies (ICLARS) (2013-2020)

- Church History Society of South Africa (CHSSA) (Vice-chairperson 2012-2020)

- Kerkregwerksgemeenskap van Suid-Afrika (Executive member 2012)

- South African Council for the Protection and Promotion of Religious Rights and Freedoms (SACRRF) (Executive member) (September 2011-2020)

- Circle of Concerned African Women Theologians (2010-2020)

\section{Church and Ecumenical Leadership Positions}

- President of the World Council of Churches (WCC) representing Africa (2013-2020)

- Member of the Permanent Committee of Consensus and Collaboration of the WCC (2013-2020)

- Member of the Central Committee of the WCC (2013-2020)

- Member of Gender Task Team the World Communion of Reformed Churches

- Member of the Procedures Task team of the WCRC

- Member of The Pan African Women's Ecumenical Empowerment Network (PAWEEN)

- Moderator of Ecumenical Consultation on The Churches advocacy Role for Children's Right at WCC in Busan, Korea: 30 October 2013-10 November 2013

- Moderator of Public Issues Committee of the World Communion of Churches (WCRC) at Grand Rapids (18-28 June 2010)

- Moderator of the URCSA General Synod (2012-2016). first female elected as moderator of URCSA

- Vice moderator of the URCSA General Synod (2008-2012). First female elected on the moderamen of URCSA

- Church law expert on the Permanent Judicial Commission of the Regional Synod Cape of the URCSA (2002-2020)

- Actuarius (church law expert) (2002-2010). First female elected as actuarius.

\section{Community Interaction}

\section{Service in Faculty and University}

- Head of Unit for Law and Religion at the Beyers Naude Centre at the Faculty of Theology, US

- Acting chair of Social Impact Committee, 2018 
- Acting chair of Transformation Committee

- Acting departmental chair

\section{Publications}

\section{Articles in Accredited Journals}

2020. "Whose Land Is It Anyway? A Historical Reflection on the Challenges URCSA Encountered with Land and Property Rights." Studia Historiae Ecclesiasticae 46 (2): \#7359. https://doi.org/10.25159/2412-4265/7359

2020. "Blackness as an Ontological Symbol: The Way Forward." Review \& Expositor 117 (1): 101-13. https://doi.org/10.1177/0034637320904718

2019. "A History of Gender Insensitivity in URCSA." Studia Historiae Ecclesiasticae 45 (3): \#6250. https://doi.org/10.25159/2412-4265/6250

2019. “Toward a Theology of Hospitality.” Ecumenical Review 71 (4): 516-29. https://doi.org/10.1111/erev.12454

2018. "The Unsettling Story about Allan Boesak's Involvement in the Struggle against Apartheid.” Studia Historiae Ecclesiasticae 44 (1): \#3552. https://doi.org/10.25159/ 2412-4265/3552

2017. "From Conciliar Ecumenism to Transformative Receptive Ecumenism." HTS Theological Studies 73 (3): \#4353. https://doi. org/10.4102/hts.v73i3.4353

2016. "From Justifying War to Justifying Peace: A Historical Overview of the Discourse in Ecumenical Circles (1905-2014).” Studia Historiae Ecclesiasticae 42 (1). http://dx.doi.org/10.17159/2412-4265/2016/94

2014. "The Belhar Confession in Its Historical Context." Nederduitse Gereformeerde Teologiese Tydskrif 55 (1-2): 301-24. https://doi.org/10.5952/55-1-2-527

2014. "The Remarkable Career of Christina Landman, Pioneer Feminist Theologian, Rooted in the Reformed Tradition." Studia Historiae Ecclesiasticae, 40 (supplement 1). http://www.scielo.org.za/pdf/she/v40s1/06.pdf

2013. "The Search for a Common Understanding with Regard to Ecology and Justice in the Uniting Reformed Church in Southern Africa." Studia Historiae Ecclesiasticae 39 (2). http://www.scielo.org.za/pdf/she/v39n2/02.pdf

2013. "The Uniting Reformed Church in Southern Africa's Enactment on Church Judicial and Legal Issues." Nederduitse Gereformeerde Teologiese Tydskrif 54 (supplement 4): 101-113. https://doi.org/10.5952/54-0-294 
2013. "The Belhar Confession: Born in the Struggle against Apartheid in Southern Africa, Guiding Light Today." Studia Historiae Ecclesiasticae 39 (1).

http://www.scielo.org.za/pdf/she/v39n1/07.pdf

2012. "Michel Foucault se historiografiese benadering as lens in historiese ondersoeke." Acta Theologica 32 (1): 78-95. http://dx.doi.org/10.4314/actat.v32i1.5

2012. "Die stryd om die aard en omvang van die tugreg by die Nederduitse Gereformeerde Sendingkerk (1881-1994)." HTS Theological Studies 68 (1):

\#1007.http://dx.doi.org/10.4102/hts.v68i1.1007

2012. "Die reis met kerkeenwording tussen die Verenigende Gereformeerde Kerk in SuiderAfrika en die Nederduitse Gereformeerde Kerk in Afrika." Verbum et Ecclesia 33 (1): \#724. http://dx.doi.org/10.4102/ve.v33i1.724

2011. "Patriarchy as Empire: A Theological Reflection." Studia Historiae Ecclesiasticae 37 (supplement): 259-270.http://www.scielo.org.za/pdf/she/v37n3/03.pdf

2011. "Control, Secede, Vested Rights and Ecclesiastical Property." Studia Historiae Ecclesiasticae. 37 (2). http://www.scielo.org.za/pdf/she/v37n2/05.pdf

2011." The Institutionalisation of Christian Women's Organisations: From Docile Recipients to Agents of Change." Studia Historiae Ecclesiasticae 37 (1): 105-119. http://hdl.handle.net/10500/4616

2011. "Die kerkreg en kerkregering van die Nederduitse Gereformeerde Sendingkerk (18811915)." Nederduitse Gereformeerde Teologiese Tydskrif 52 (1): 194-204. https://doi.org/10.5952/52-1-17

2008. "Rejection of Division.” Reformed World 58 (2-3): 105-114.

http://wcrc.ch/wp-content/uploads/2015/05/ReformedWorld-58-2.pdf

2005. (Co-authored with Christina Landman) "Vroue in die teologiese antropologie in die Afrikaanse Gereformeerde tradisie.” Studia Historiae Ecclesiasticae 31 (1): 203-222. http://uir.unisa.ac.za/handle/10500/4367

\section{Chapters in Academic Books}

2019. "A Critical Reflection of the Role of 'Context' in Discernment, Decision-Making and Reception.” In Leaning into the Spirit: Pathways for Ecumenical and Interreligious Dialogue, edited by V. Miller, T. Moxon, and T. Pickard, 49-64. Cham: Palgrave Macmillan. https://doi.org/10.1007/978-3-030-19997-5_5

2019, "Freedom of Religion in South Africa." In Freedom of Religion at Stake: Competing Claims among Faith Traditions, States, and Persons, edited by Dion Foster, Elisabeth Gerle and Göran Gunner. Eugene: Wipf and Stock. 
2018. The Quest for Religious Pluralism in Post-apartheid South Africa.” In Religion, Pluralism, and Reconciling Difference, edited by W. Cole Durham Jr. and Donlu Thayer. Abingdon: Routledge.

2017. "Acceptance, Adoption, Advocacy, Reception and Protestation: A Chronology of the Belhar Confession." In Belhar Confession. The Embracing Confession of Faith for Church and Society, edited by Mary-Anne Plaatjies-Van Huffel and Leepo Modise, 1-96. Stellenbosch: Sun Press.

2017. "Natural Law in the Reformed Tradition." In Christianity and Natural Law: An Introduction, edited by Norman Doe, 121-139. Cambridge: Cambridge University Press. https://doi.org/10.1017/9781316890615

2017. (Co-authored with Anlené Taljaard). "His Didactics." In Russel Botman A Tribute (1953-2014), edited by Albert Grundling, Ruda Landman and Nico Koopman, 101-114. Stellenbosch: Sun Press.

2016. "Afrikaans: Voertaal, kerktaal, strydtaal in die Nederduitse Gereformeerde Sendingkerk en die Verenigende Gereformeerde Kerk in Suider-Afrika." In Ons kom van vêr: Bydraes oor Bruin Afrikaanssprekendes se rol in die ontwikkeling van Afrikaans, edited by W.A.M. Carstens and M. Le Cordeur, 72-92. Cape Town: Naledi.

2015. "A Chronology of the Political and Theological Activity at the University of the Western Cape during the Heyday of the Struggle against Apartheid." In Umstrittene Beziehungen/Contested Relations: Protestantismus zwischen dem südlichen Afrika und Deutschland von den 1930er Jahren bis in die Apartheidzeit/Protestantism between Southern Africa and Germany from the 1930s to the Apartheid Era, edited by Hanns Lessing, Tilman Dedering, Jürgen Kampmann, Dirkie Smit et al., 500-508.Wiesbaden: Harrassowitz. https://doi.org/10.2307/j.ctvc2rn5t.33

2014. "The Relevance of Reformed Church Polity Principles: Revisiting the Concept." In Protestant Church Polity in Changing Contexts 1, edited by Allan J. Jansen and Leo J. Koffeman, 31-50. Münster: LIT Verlag.

2013. "Reading the Belhar Confession as a Historical Text." In Reformed Churches in South Africa and the Struggle for Justice: Remembering 1960-1990, edited by Mary-Anne Plaatjies-Van Huffel and Robert Vosloo, 329-345. Stellenbosch: Sun Press.

2013. "Response to: 'Empowering Those Who Suffer Domestic Violence: The Necessity of Different Theological Imagery,' by Anne-Claire Mulder.” In Fragile Dignity, Intercontextual Conversations on Scriptures, Family, and Violence, edited by L. Juliana Claassens and Klaas Spronk, 219-226. Atlanta: Society of Biblical Literature.

2011. "Dirk Smit: An Apologist for Confessions." In Living Theology: Essays Presented to Dirk J. Smit on His Sixtieth Birthday, edited by Len Hansen, Nico Koopman and Robert Vosloo. Wellington: Bible Media. 
2008. (Co-authored with Dineo Seloana). "About the Empowerment of Women in Postapartheid South Africa: A Post-Structural Approach.” In From Our Side: Emerging Perspectives on Development and Ethics, edited by Steve de Gruchy, Nico Koopman and Sytse Strijbos, 87-100.Amsterdam: Rozenberg.

2008. "Women in the Theological Anthropology of Oom Beyers Naudé." In Oom Bey for the Future: Engaging the Witness of Beyers Naudé, edited by Len Hansen and Robert Vosloo, 109-120. Stellenbosch: Sun Press.

\section{Popular Publications}

2017. "Anna Tempo: Suster Nannie - onbesonge sendeling." In Die hart van God: Verhale van vroue in sending, edited by Liezel Joubert and Isabel Murray, 89-103. Wellington:

Christelike Lektuurfonds.

2010. "Apartheid Then and Now." In Cruelty and Christian Witness: Confronting Violence at Its Ugliest. Geneva: WCC.

2010. "Boer op God se grond: Grondhervorming en die Bybel." In God praat-leef luisterryk, edited by Chris Jones. Wellington: Bible Media.

2010. “'Sol iustitiae illustra nos': Nadenke oor die imago Dei en Litnet (2011-2012).” 